\title{
IdeAs
}

Idées d'Amériques

18 | 2021

Frontières dans les Amériques - Intégration, sécurité et migrations

\section{A contingência pandêmica e os impactos migratórios: uma análise dos atos normativos de fechamento da fronteira entre Brasil e Venezuela}

Pandemic contingency and migratory impacts: an analysis of normative acts to close the border between Brazil and Venezuela

Contingence pandémique et impacts migratoires : une analyse des actes normatifs pour fermer la frontière entre le Brésil et le Venezuela

\section{Nicolli Bernardes Ribeiro e Lucas Sena}

\section{OpenEdition}

Journals

Edição electrónica

URL: https://journals.openedition.org/ideas/11785

DOI: 10.4000/ideas. 11785

ISSN: 1950-5701

\section{Editora}

Institut des Amériques

\section{Refêrencia eletrónica}

Nicolli Bernardes Ribeiro e Lucas Sena, «A contingência pandêmica e os impactos migratórios: uma análise dos atos normativos de fechamento da fronteira entre Brasil e Venezuela ", IdeAs [Online], 18| 2021, posto online no dia 01 outubro 2021, consultado o 21 outubro 2021. URL: http:// journals.openedition.org/ideas/11785 ; DOl: https://doi.org/10.4000/ideas.11785

Este documento foi criado de forma automática no dia 21 outubro 2021.

\section{cc) (1)}

IdeAs - Idées d'Amériques est mis à disposition selon les termes de la licence Creative Commons Attribution - Pas d'Utilisation Commerciale - Pas de Modification 4.0 International. 


\section{A contingência pandêmica e os impactos migratórios: uma análise dos atos normativos de fechamento da fronteira entre Brasil e Venezuela}

Pandemic contingency and migratory impacts: an analysis of normative acts to close the border between Brazil and Venezuela

Contingence pandémique et impacts migratoires : une analyse des actes normatifs pour fermer la frontière entre le Brésil et le Venezuela

Nicolli Bernardes Ribeiro e Lucas Sena

\section{Introdução}

1 No dia 30 de janeiro de 2020, a Organização Mundial da Saúde, (OMS) declarou estado de Emergência de Saúde Pública de Importância Internacional (ESPII) - relacionado à pandemia causada pelo vírus SARS-CoV2, também conhecida como "novo coronavírus", e com sua doença caracterizada como COVID-19 (WHO, 2020). A própria inserção de uma doença viral em um paradigma de intensa mobilização de pessoas, bens e mercadorias já traz um primeiro grupo de externalidades contingentes relacionadas à territorialidade. Uma primeira consequência desta alta transmissibilidade se caracteriza por uma aparente contradição: por um lado há uma unidade viral (apesar do caráter mutável do vírus, identificável pela sua tipagem genética) e, por outro, uma multiplicidade cultural-responsiva. Sendo assim, todos os países compartilham o fato empiricamente observável da incidência e chegada do vírus SARS-CoV-2 em seu território, mas, ao mesmo tempo, cada um responde a esta chegada de uma maneira específica a partir de suas características políticas e culturais. 
2 Sendo assim, da mesma forma como a expressão nacional e regional é plural, as consequências pandêmicas no cotidiano também se expressam nos inúmeros locais de significados interligados entre si e em diversas vertentes - social, política e econômica. Há, então, outra constante neste caleidoscópio, qual seja, a interligação recíproca entre os campos significativos. Esta constatação e sua relação com o paradigma institucional do Estado de Direito traz algumas perguntas: será que a normatividade subjacente aos atos administrativos editados durante o período pandêmico expressa os conflitos sociais identificados no tecido político pré-pandêmico? Além disso, esta normatividade também serve como modelo de análise para identificar o ethos ideológico de um complexo político específico? Por fim, será que um discursivo embate pandêmico pode ser usado como instrumento de violação de direitos humanos?

3 Para tentar responder esta e outras perguntas, propor-se-á neste artigo uma breve análise comparativa entre os atos normativos publicados pela República Federativa do Brasil, direcionados aos imigrantes nacionais da República Bolivariana da Venezuela, ou seja, partiremos da correlação entre as informações abstraídas das Portarias editadas pelo Governo brasileiro - na tentativa de controle da pandemia - para trazer as questões inseridas na decisão de fechamento da fronteira Brasil-Venezuela. Espera-se, com isso, contribuir para o debate público e acadêmico sobre a utilização de normas jurídicas como instrumento e expressão de seletividade migratória, para além das consequências primárias acopladas ao significado de uma determinada legislação. Assim, analisaremos a Portaria Interministerial $n^{\circ} 120 / 2020$ e a Portaria Interministerial $n^{0}$ 255/2020 com o intuito de trazer à baila uma abordagem jurídica que não se contenta com a simples aparência de uma lei, com o discurso préestabelecido sobre seu significado, mas, ao contrário, que se utiliza tanto da análise dos atos normativos em questão quanto de fontes externas ao direito para entender como fatores sociais e políticos podem influenciar e serem usados como mecanismo de restrição das migrações para um grupo determinado.

4 Assim, na primeira parte do artigo, dentre as diversas fontes que podem ser utilizadas no estudo da práxis jurídica - leia-se leis e portarias - utilizaremos as referências já estabelecidas no estudo das migrações internacionais para constituir um arcabouço que embase nossa discussão, fazendo um trabalho de breve reconstrução do ethos epistemológico que subjaz ao tema e traçando a gênese da discussão em comento. A partir daí, passaremos pelas discussões específicas das relações políticas analisadas, situadas a partir da publicação da Portaria $\mathrm{n}^{\mathrm{0}}$ 120/2020 para, por fim, chegar aos possíveis efeitos biopolíticos que a contingência pandêmica direcionada à uma nacionalidade específica, a venezuelana, traz ao debate de direitos humanos.

\section{O contexto migratório brasileiro pré-pandemia}

5 A restrição de acesso e fechamento de fronteiras não é um fenômeno que se inaugura a partir da pandemia da COVID-19. Em diferentes e inúmeros contextos, o Brasil e outros países adotaram medidas de contenção e controle fronteiriço - uma das primeiras medidas restritivas foi adotada pelo Brasil ainda na década de 1930, quando o país estabelece quotas de entrada para a imigração internacional (Fernandes, D. \& A. Leão, 2020). Sendo assim, antes de entrar no contexto de fechamento de fronteiras invocado por esse momento de pandemia, precisamos contextualizar e estabelecer o cenário da gestão de fronteiras em condições normais, nesse caso, em um mundo pré-pandêmico. 
Neste sentido, destacaremos dois pontos importantes para a presente análise: a) a conjuntura dos fluxos migratórios da região e como o Brasil se localiza nela, principalmente no que se refere à migração venezuelana; b) a política migratória brasileira e seus avanços a partir do ano de 2017.

6 Não é incomum pensar no Brasil como um país mais aberto à migração, com adoção de políticas migratórias menos restritivas e fronteiras menos rígidas. No entanto, se analisarmos historicamente a política migratória brasileira e o funcionamento de abertura e entrada de imigrantes, podemos notar que as fronteiras brasileiras mantêm suas "portas não tão abertas" (Villarreal M., 2019). Os fluxos mais recentes com destino ao Brasil são marcados pelo sentido Sul-Sul, ou seja, um fluxo de pessoas oriundas de países do Sul global, deslocando-se em direção a outros países do Sul global. ${ }^{1}$ Contudo, os fluxos migratórios para o país foram marcados também por um processo de endurecimento do controle da migração, que incorporou e fomentou uma política de atração de imigrantes oriundos do Norte global, em detrimento de imigrantes do Sul, inclusive dos outros países da América Latina (Pelligrino A., 2003 ; Martínez J. \& C. Orrego, 2016).

7 Seja pelo processo de substituição de mão de obra escravizada, seja pelo processo de tentativa de embranquecimento da população, durante os séculos XIX e XX o Brasil optou e incentivou, por anos, a migração de europeus para o país (Seyferth G., 1986, 1997, 2011 ; Kowarick L., 1994; Koifman F., 2012; Lesser J., 2015; Villarreal M., Echart E. \& M. Carballo, 2019). Conforme Jeffrey Lesser (2015, p. 53), a “ideologia de branqueamento foi de importância crucial na formulação da política de imigração brasileira moderna". Nessa perspectiva, as portas do Brasil estavam bem abertas para um fluxo específico de imigrantes: os do Norte global, principalmente os europeus.

8 É sabido que a fronteira terrestre do Brasil é extensa e faz limite com a grande maioria dos países da América Latina, entre eles a Venezuela, país que foi um expoente receptor de imigrantes e que hoje enfrenta uma crise econômica, política, social e humanitária das mais graves na história do país e da região e que resultou em "um aumento de 8 mil por cento no número de venezuelanos buscando o reconhecimento do status de refúgio no mundo desde 2014, principalmente nas Américas"2. Em 2018, a partir do Decreto no 9.285/2018, o Brasil reconheceu a situação de vulnerabilidade decorrente de fluxo migratório provocado pela crise humanitária da República Bolivariana da Venezuela. Também no ano de 2018, o governo brasileiro publicou a Portaria Interministerial no 9/2018, que permitia residência temporária aos imigrantes oriundos de países fronteiriços que estivessem em território brasileiro e não fizessem parte do Acordo de Residência para Nacionais dos Estados Partes do MERCOSUL e países associados, medida que contemplou os venezuelanos.

9 De acordo com os dados publicados em agosto de 2021 pela Plataforma Regional de Coordinación Interagencial para Refugiados y Migrantes de Venezuela (R4V) - em parceria com a Agência da ONU para Refugiados (ACNUR) e a Organização Mundial para as Migrações (OIM) - o país vizinho ocupava a segunda posição como o país com o maior número de deslocados no mundo, com mais de 5 milhões $^{3}$ de venezuelanos que saíram de seu país, colocando a Venezuela atrás somente da Síria - com 6,6 milhões de migrantes pelo mundo - como país com o maior fluxo de saída de pessoas. ${ }^{4}$

Os últimos dados divulgados pelo Comitê Nacional para Refugiados (CONARE) ${ }^{5}$ destacam que até o ano de 2020 o Brasil reconheceu mais de 55 mil venezuelanos como refugiados, o que representa $76,6 \%$ do total de concessões do reconhecimento da 
condição de refúgio no país. ${ }^{6}$ Atualmente o contingente de venezuelanos no Brasil chega a 261,4 mil. Em relação aos outros países da América Latina, Colômbia, Peru, Chile e Equador despontam como os principais receptores de venezuelanas e venezuelanos na região. ${ }^{7}$ Em dados gerais sobre a migração de pessoas de outras nacionalidades para o Brasil, a situação do país em comparação com os países vizinhos não é muito diferente e, apesar de o Brasil ter sido por muitos anos um dos principais destinos para imigrantes na região, a Argentina, a Colômbia e o Chile apresentam números superiores aos do Brasil. A título de informação, de acordo com os dados atualizados até meados do ano de 2020 , o Brasil tem 1,1 milhão de imigrantes (0,5\% da população), ao passo que a Argentina tem 2,3 milhões de imigrantes ( $\%$ da população), a Colômbia aparece com 1,9 milhão de imigrantes ( $3,7 \%$ da população) e o Chile com um total de 1,6 milhão de imigrantes ( $8,6 \%$ da população). ${ }^{8}$

$\mathrm{O}$ segundo ponto do contexto migratório brasileiro pré-pandemia em comento, se refere à política de migração brasileira. Importa explicitar, assim, o tratamento e, principalmente, a concepção que o Estado brasileiro teve em relação à imigração e, consequentemente, aos imigrantes durante as quase quatro décadas em que vigorou o Estatuto do Estrangeiro (Lei $\mathrm{n}^{\mathrm{0}}$ 6.815/1980), documento que regia e representava a política de migração brasileira, até entrar em vigor a nova legislação migratória do Brasil, a partir da publicação da Lei de Migração (Lei n 13.445/2017), em 24 de maio de 2017.

12 Um primeiro aspecto sobre essa questão é o período em que o antigo documento é sancionado. $O$ Estatuto do Estrangeiro entra em vigor ainda durante a Ditadura Militar do Brasil, o contexto denuncia o teor e a visão que o Brasil - durante um Estado de Exceção - tinha do imigrante (Sprandel M. A., 2015; Kenicke P. H., 2016; Oliveira A., 2017; Assis G., 2018). A matéria da política migratória estava inserida em uma lógica da segurança nacional e, por sua vez, partia de uma "lógica do inimigo" em que o "Outro" representava uma ameaça ao país, não à toa o documento opta pelo termo "estrangeiro" ao invés de imigrante. Estrangeiro é aquele que é estranho, que não pertence àquele espaço (Appadurai A., 2009; Albuquerque Júnior D., 2016; Simi G., 2020).

o Estatuto do Estrangeiro também estava incorporado em uma perspectiva da segurança nacional e a imigração representava uma ameaça nacional. Essa ideia estava exposta logo no início do Estatuto, que no seu artigo $2^{\circ}$ expressava que "na aplicação desta Lei atender-se-á precipuamente à segurança nacional, à organização institucional, aos interesses políticos, sócio-econômicos e culturais do Brasil, bem assim à defesa do trabalhador nacional" (Brasil, Presidência da República, 1980).

14 O Estatuto definiu a política nacional de migração até 2017, quando a nova Lei de Migração foi publicada. A nova Lei de Migração é fruto dos esforços dos imigrantes, da sociedade civil e dos movimentos sociais na tentativa de romper com o paradigma de segurança do Estado, tirar o imigrante desse lugar de ameaça nacional e criar um novo marco migratório. A nova legislação teve origem no Projeto de Lei do Senado $\mathrm{n}^{\circ}$ 288/2013, de autoria do Senador Federal Aluísio Nunes, sendo sancionada pelo então presidente da república Michel Temer. A partir disso, são apontados elogiáveis avanços na política migratória brasileira, tais como: a não criminalização das migrações; o impedimento de prisão em caso de situação irregular; a garantia da reunião familiar; o repúdio à deportação coletiva; o combate à xenofobia, ao racismo e outras manifestações discriminatórias; a política de vistos humanitários; e outros. 
15 No entanto, entre a aprovação do Projeto e sua publicação última na forma de Lei, o presidente Michel Temer vetou pontos importantes do texto (Brasil, Presidência da República, 2017a; Vedovato L. \& G. Assis, 2018). Para citar apenas alguns vetos, destacamos: a qualificação como grupo vulnerável aos solicitantes de refúgio, as vítimas de tráfico de pessoas, as vítimas de trabalho escravo e menores desacompanhados; e a extensão da garantia e do entendimento da reunião familiar (Brasil, Presidência da República, 2017a).

16 Apesar de terem sido notados importantes avanços na política migratória a partir da adoção da Lei de Migração, com demonstrado alinhamento aos Direitos Humanos e sendo reconhecida como uma política migratória das mais humanitárias e avançadas do mundo, percebemos resquícios do pensamento anterior associado à ideia do imigrante como ameaça ao país, como fica evidenciado pela manutenção da atuação da Polícia Federal na gestão das questões relativas à migração (Kenicke P. H., 2016; Oliveira A., 2017; Assis G., 2018). Além disso, juntamente com o Ministério das Relações Exteriores, o Ministério da Justiça e Segurança Pública são dois dos principais corpos do governo federal do Brasil na coordenação das migrações no país, reunindo algumas das mais importantes atribuições na gestão da migração. Temos como exemplo a Operação Acolhida, que é responsável pelo recebimento e interiorização dos venezuelanos e venezuelanas para outros estados do Brasil - uma vez que a principal porta de acesso desse grupo de imigrantes é pelo estado de Roraima, no norte do país -, e é controlada pelo Exército brasileiro.

\section{Instrumentalização da pandemia}

17 Transferindo a análise para o momento atual, quando o Brasil e o mundo enfrentam uma das piores crises sanitárias da história, o fechamento de fronteiras passou a ser uma medida comum e regra básica entre quase todos - se não todos - os países. Apesar de não ser uma prática que se inaugura com a pandemia, o controle da fronteira para a entrada de imigrantes é a tônica deste período (Moreira J., 2020; Villarreal M., 2020; Baeninger R., 2020). Neste sentido, restrições a direitos individuais e coletivos são praticamente inerentes ao combate pandêmico. Tanto assim o é, que um dos primeiros pontos trabalhados na aplicação de medidas de restrição são as consequentes violações de direitos humanos (Ventura D., 2016a). Imaginemos, por exemplo, um momento de estado de Emergência de Saúde Pública de Importância Internacional (ESPII) baseado na disseminação de uma infecção viral aos moldes da atual COVID-19. Prontamente se fará necessária a imposição de restrições à liberdade de locomoção, um direito humano fundamental e essencial à própria condição humana de sociabilidade.

Por conta destas e de outras questões relacionadas, aspectos jurídicos acabam adentrando neste ethos e devem ser ponderados pela ação normativa de entidades políticas. Em última análise e fazendo uma aproximação com a pandemia causada pelo vírus SARS-CoV2, as restrições de liberdade, com base nas recomendações médicocientíficas, começam a ser apontadas como essenciais e necessárias à saúde pública. ${ }^{9}$ Entretanto, o momento de convulsão no sistema de saúde pública também pode ser utilizado como justificativa para ações que não seriam toleradas pelo coletivo social em momentos de normalidade sanitária. Assim, algumas considerações devem ser colocadas neste momento. 
19 Em primeiro lugar, fala-se de uma análise dos atos políticos estatais. Sendo assim, estando no paradigma democrático de direito, imagina-se que essa forma de agência terá alguma forma de expressão nos atos normativos editados pelo governo do Brasil. 0 próximo passo, então, é tomar a normatividade, o direito, como uma arena significativa em disputa, desnaturalizando-se sua expressão jurídica e buscando observar as relações de poder ou, como diria Ferdinand Lassale (1988), os fatores reais de poder ${ }^{10}$ subjacentes a uma eventual produção jurídica.

Como falado na introdução, a disseminação global da COVID-19 traz algumas contradições ao arranjo político-institucional que definimos como Estado. Por um lado, temos a crescente interconexão global e, por outro, temos o acirramento de posições nacionais. Um elemento intrínseco a este debate está na análise fronteiriça, a ficção normativa que cria linhas imaginárias entre coletivos sociais que convencionou-se denominar "países". As suas diferentes respostas causam diferentes consequências e impactos da enfermidade viral. Um exemplo se dá na relação Brasil-Paraguai: enquanto o governo central do Brasil optou por uma visão negacionista e uma aposta na chamada "imunização de rebanho" ao custo de inúmeras vidas, o Paraguai optou por uma restrição de locomoção mais restrita (popularmente chamada de lockdown) com uma consequente diminuição drástica no número de mortes, especialmente quando comparado com seu vizinho ao leste. Por conta desta diferença fática na abordagem pandêmica, o Governo do Paraguai optou por fechar suas fronteiras para o Brasil. Entretanto, este caso específico fica dentro de um contexto que podemos denotar como puramente pandêmico, ou seja, a chefia executiva dos dois países possuíam uma boa relação entre si - e até uma discursiva afinidade ideológica. Repete-se o questionamento da introdução: e se a relação entre países fosse de antagonismo?

21 Se as intenções políticas podem ser expressas nos seus atos normativos, e se as fronteiras são um conceito jurídico-político de especial importância no atual zeitgeist de emergência, o presente trabalho irá testar estas duas hipóteses com o estudo dos atos normativos sobre as relações de fronteira expedidos pelo executivo federal brasileiro no contexto da pandemia causada pelo vírus SARS-CoV2. É quase um lugar-comum na abordagem epistemológica ocidental o início de uma análise pelos aspectos gerais do objeto de pesquisa e, a partir daí, deslocar-se para a especificidade, partindo-se do pressuposto da expressão de elementos do geral no fenômeno específico. Sendo assim, se formos pensar numa abordagem político-jurídica de saúde pública relacionada ao combate pandêmico nas fronteiras, imaginar-se-á que, até pelo tamanho geográfico da fronteira brasileira, primeiro seria editado um ato geral que regulasse as diversas relações fronteiriças ou, pelo menos, estabelecesse normas gerais de atuação.

No caso político brasileiro aconteceu o inverso. O primeiro ato normativo neste contexto que se relacionava com o conceito de fronteira foi a Portaria Interministerial $\mathrm{n}^{\mathrm{o}}$ 120, expedida em 17 de março de 2020. Conforme seu preâmbulo, a Portaria "dispõe sobre a restrição excepcional e temporária de entrada no País de estrangeiros oriundos da República Bolivariana da Venezuela, conforme recomendação da Agência Nacional de Vigilância Sanitária - Anvisa" (Brasil, Ministério da Justiça e Segurança Pública, 2020a).

Seu primeiro artigo repete o preâmbulo e faz remissão à lei específica que instituiu o Estado de Emergência nacional relacionado à COVID-19, qual seja, a Lei no 13.979, de 6 de fevereiro de $2020 .{ }^{11}$ Seu artigo segundo trata sobre a duração das restrições estabelecidas nesta primeira Portaria, fixando o prazo de quinze dias, a entrada por 
"rodovias ou meios terrestres", com este prazo "podendo ser prorrogado, conforme recomendação técnica e fundamentada da Agência Nacional de Vigilância Sanitária Anvisa". Este argumento aparentemente técnico reaparece no terceiro artigo da Portaria, ressaltando- se, em seus dois incisos "a dificuldade de o Sistema Único de Saúde brasileiro comportar o tratamento de estrangeiros infectados pelo coronavírus SARS-CoV2" e "da dificuldade de impedir a disseminação do coronavírus SARS-CoV2" (Brasil, Ministério da Justiça e Segurança Pública, 2020a).

Os artigos quarto e quinto tratam de algumas exceções às regras de impedimento descritas acima, excepcionando-se o tráfego fronteiriço de "brasileiro, nato ou naturalizado; ao imigrante com prévia autorização de residência definitiva em território brasileiro; ao profissional estrangeiro em missão a serviço de organismo internacional, desde que devidamente identificado; ao funcionário estrangeiro acreditado junto ao Governo brasileiro". Além disso, o tráfego rodoviário de cargas e a "execução de ações humanitárias transfronteiriças previamente autorizada pelas autoridades sanitárias locais" seguiam sendo possíveis (Brasil, Ministério da Justiça e Segurança Pública, 2020a).

Se a própria edição desta portaria específica à Venezuela já nos traz algumas questões sobre sua conveniência e seus motivos de existência, tratando de forma diferenciada um país fronteiriço, até mesmo violando o princípio constitucional expresso de igualdade entre Estados e também o mandamento de formação de uma comunidade latino-americana de nações, conforme artigo $4^{\circ}$ da Constituição Federal de 1988, a redação do artigo 6으, inciso II da Portaria $\mathrm{n}^{\circ}$ 120/2020 expõe mais claramente as relações de poder subjacentes. Segundo este inciso, o descumprimento da portaria implicará na "responsabilização civil, administrativa e penal" e na "deportação imediata do agente infrator e a inabilitação de pedido de refúgio" (Brasil, Ministério da Justiça e Segurança Pública, 2020a). Entretanto, é importante explicitar desde já as graves violações de direitos humanos, da própria Lei de Migração e da ordem jurídica internacional pela contradição com princípios básicos da relação entre países como, por exemplo, o princípio do non refoulement.

O segundo ato do Governo Federal em direção ao controle fronteiriço se deu com a publicação, no dia 19 de março de 2020, da Portaria $n^{0} 125 / 2020$, que trata sobre o fechamento das fronteiras terrestres do Brasil, ou seja, impedia a entrada de pessoas vindas da Argentina, Bolívia, Colômbia, Guiana Francesa, Guiana, Paraguai, Peru e Suriname - a Portaria $\mathrm{n}^{\mathrm{0}} 132$, de 22 de março de 2020, tratou especificamente do impedimento de entrada de pessoas oriundas do Uruguai. No dia 23 de março de 2020, a Portaria $\mathrm{n}^{\circ} 133$ é publicada e restringe, pela primeira vez, o acesso de imigrantes por via aérea. No entanto, a Portaria $\mathrm{n}^{\circ} 133$ não restringia o acesso de nacionais de todos os países para o Brasil, limitando o acesso apenas das pessoas que estivessem vindo da China, Islândia, Noruega, Suíça, Reino Unido da Grã-Bretanha e Irlanda do Norte, Austrália, Irã, Japão, Malásia, Coreia do Sul e dos países que compõem a União Europeia. o fechamento total da fronteira por via aérea para todos os países ocorre 10 dias depois do fechamento da fronteira com a Venezuela e 8 dias depois do fechamento das fronteiras terrestres, a partir da publicação da Portaria no 152, de 27 de março de 2020.

Esse retorno cronológico nos mostra que a primeira medida que o Governo brasileiro tomou em relação ao fechamento de fronteiras, teve direcionamento específico a um grupo de imigrantes que nesse momento representa um grupo vulnerável, de pessoas afetadas, no geral, por uma grave crise humanitária vivida pela Venezuela. De igual 
modo, a segunda medida do Estado brasileiro referente ao controle das fronteiras estendia a limitação de acesso terrestre para os outros países da fronteira com o Brasil. Essas duas primeiras medidas, em especial, nos mostram que a preocupação inicial estava centrada no ingresso de imigrantes que representavam os grupos migratórios que normalmente dispõem de menos recursos para fazerem a travessia de fronteira por via aérea.

Enquanto a Portaria no 120/2020 foi publicada em 17 de março de 2020, outra norma geral sobre fronteiras, a Portaria $\mathrm{n}^{0} 255 / 2020$, foi editada no dia 22 de maio de $2020 .^{12}$ Mais do que uma simples diferença formal de datas, argumentamos que estes pequenos detalhes são indiciários da relação e prioridades governamentais neste período de emergência sanitária. Com base em seu preâmbulo, este ato normativo "dispõe sobre a restrição excepcional e temporária de entrada de estrangeiros, de qualquer nacionalidade, conforme recomendação da Anvisa", o que é repetido no seu artigo primeiro (Brasil, Ministério da Justiça e Segurança Pública, 2020d). No que diz respeito ao presente artigo, a análise será restrita aos aspectos excepcionais deste ato e das possíveis violações de direitos humanos inerentes a ele.

Sendo assim, um primeiro ponto de atenção é o parágrafo quinto do artigo $4^{\circ}$ da Portaria $\mathrm{n}^{\circ} 255 / 2020$. Este artigo versa a respeito das pessoas sobre as quais a restrição de locomoção não incidirá, como o brasileiro nato ou naturalizado (inciso I), imigrante com residência de caráter definitivo no território brasileiro (inciso II), profissional estrangeiro a serviço de organismo internacional (inciso III), passageiro em trânsito internacional (inciso IV), funcionário estrangeiro acreditado junto ao Governo brasileiro (inciso V) e, no seu inciso VI, alínea "a", o estrangeiro que for cônjuge, companheiro, filho, pai ou curador de brasileiro; alínea "b", estrangeiro cujo ingresso seja autorizado especificamente pelo Governo brasileiro em vista do interesse público ou por questões humanitárias; e, alínea "c", o estrangeiro portador de Registro Nacional Migratório (Brasil, Ministério da Justiça e Segurança Pública, 2020d).

Fizemos questão de ressaltar expressamente três hipóteses, a do inciso II, e as alíneas "a" e "c" do inciso VI, tendo como motivo o citado parágrafo quinto do mesmo artigo $4^{\circ}$. Nas palavras deste parágrafo, "as hipóteses de que tratam o inciso II e as alíneas 'a' e 'c' do inciso VI do caput não se aplicam a estrangeiros provenientes da República Bolivariana da Venezuela" (Brasil, Ministério da Justiça e Segurança Pública, 2020d).

Em outras palavras, mesmo que a pessoa seja um imigrante venezuelano com residência definitiva no Brasil; um cônjuge, companheiro, filho, pai ou curador de brasileiro, ou uma pessoa com Registro Nacional Migratório, ela terá sua entrada impedida por ser "proveniente da República Bolivariana da Venezuela". Digamos, então, que a pessoa seja cônjuge de uma brasileira e teve de sair do país a trabalho. Com o advento da pandemia da COVID-19 esta pessoa teve de sair do local onde estava face as medidas de isolamento. Com base na Portaria $n^{\circ} 255 / 2020$, mesmo a pessoa estando completamente ligada ao Brasil, sem residência no seu país de origem, ficaria impedida de entrar no território nacional.

Ainda, a Portaria no 255/2020 também excepciona o tráfego fronteiriço para os residentes de "cidades-gêmeas, mediante a apresentação de documento de residente fronteiriço ou outro documento comprobatório, desde que seja garantida a reciprocidade no tratamento ao brasileiro pelo país vizinho" (Artigo 5², Inciso II). Entretanto, este direito, segundo artigo 5o, parágrafo primeiro, "não se aplica à 
fronteira com a República Bolivariana da Venezuela" (Brasil, Ministério da Justiça e Segurança Pública, 2020d).

Desta forma, fica patente que as Portarias Interministeriais publicadas pelo governo brasileiro tiveram a entrada de venezuelanas e venezuelanos no Brasil como principal objeto de restrição. Tais medidas podem ser compreendidas como reflexo de uma seletividade migratória a partir do momento em que direciona os atos normativos à uma nacionalidade específica, determinando quem não pode entrar no país.

\section{Considerações finais}

No momento em que as primeiras Portarias Interministeriais foram sancionadas, o epicentro da pandemia de COVID-19 não estava nos países de fronteira com o Brasil. Pelo contrário, as situações mais agravadas estavam acontecendo na Itália, Espanha, China e Irã, países que, de modo direto, seus nacionais não acessam ao Brasil por via terrestre, sendo necessário o uso de transportes aéreo ou marítimo. A justificativa sanitária para o fechamento das fronteiras com os países da América do Sul, nesse sentido, não se sustenta, tendo em vista que no intento de minimizar o contato e o contágio pelo novo vírus, as primeiras medidas de restrição de acesso, segundo as justificativas para a publicação das portarias em análise, teriam de ser aplicadas em direção aos países que demonstravam, naquele momento, passar por uma situação mais dramática em relação ao vírus da COVID-19.

Ao que se sabe, os primeiros casos no Brasil de coronavírus chegaram através de brasileiros que cruzaram as fronteiras por via aérea regressando de países não fronteiriços, como Itália e Estados Unidos. Esses brasileiros, turistas em outros países, são os chamados "cidadãos do mundo" (Bauman Z., 1999), que detém recursos para se deslocarem de forma mais segura e livre; não se deslocam por necessidade de assegurar a sua integridade e protegerem suas vidas, como o caso de refugiados e alguns imigrantes. Contraditoriamente, as primeiras medidas trouxeram implicações diretas para os grupos mais vulneráveis, como o caso dos venezuelanos. Essa é uma das faces da seletividade das migrações recentes: priva-se a entrada de quem precisa de proteção internacional, no primeiro momento.

Os mais prejudicados com o fechamento das fronteiras são os que mais precisam fazer o deslocamento e precisam de proteção internacional, ou seja, os imigrantes e refugiados. No entendimento de que os que saem dos seus países em busca do reconhecimento da condição de refugiado, não se deslocam por sua vontade, mas são forçados a migrar, precisam atravessar a fronteira para protegerem suas vidas. $O$ solicitante de refúgio, por exemplo, não é uma pessoa que migra porque desejou fazer. 0 deslocamento forçado, como no caso do refúgio, ocorre porque há necessidade primeira de sobrevivência e não porque as fronteiras são mantidas abertas. $O$ fechamento das fronteiras, no entanto, os colocam em uma situação mais arriscada e perigosa para a travessia, uma vez que além do fechamento não ser possível ao longo de toda a fronteira, a tentativa de se deslocarem não se anula; busca-se formas alternativas, e por vezes mais inseguras, para fazerem a travessia. As causas e motivações para a migração não cessam de acontecer porque há um vírus circulando ou porque as fronteiras estão fechadas neste momento. 


\section{BIBLIOGRAFIA}

ACNUR (Agência da ONU para Refugiados), Venezuela, Disponível em: https://www.acnur.org/ portugues/venezuela/, Acesso em 01 de ago. de 2020.

ACNUR (Agência da ONU para Refugiados), Dados sobre Refúgio, Disponível em: https:// www.acnur.org/portugues/dados-sobre-refugio/, Acesso em 01 de ago. de 2020.

ACNUR (Agência da ONU para Refugiados), Brasil torna-se o país com maior número de refugiados venezuelanos reconhecidos na América Latina, Disponível em: https://www.acnur.org/portugues/ 2020/01/31/brasil-torna-se-o-pais-com-maior-numero-de-refugiados-venezuelanosreconhecidos-na-america-latina/, Acesso em 01 de ago. de 2021.

Albuquerque Júnior, Durval Muniz, Xenofobia: medo e rejeição ao estrangeiro, São Paulo: Cortez Editora, 2016.

Appadurai, Arjun, o Medo ao Pequeno Número: ensaio sobre a geografia da raiva, São Paulo: Illuminuras, 2009.

Assis, Gláucia, A Nova Lei de Migração: avanços e desafios, In: Baeninger, Rosana; Bógus, Lucia; Vedovato, Luís Renato; Fernandes, Duval; et al (org), Migrações Sul-Sul, Campinas: Núcleo de Estudos de Populações (NEPO/Unicamp), 2018, pp. 609-623.

Baeninger, Rosana; Mesquita, Romeu Bonk, "Integração regional e fronteiras: desafios para a governança das migrações internacionais na América Latina", Revista Transporte y Territorio, v. 15, 2016.

Baeninger, Rosana, "Migrações internacionais e a pandemia de COVID-19: mudanças na era da migração?”, In. Baeninger, Rosana; Vedovato, Luís Renato; Nandy, Shailen, Migrações Internacionais e a Pandemia da COVID-19, Campinas: NEPO/UNICAMP, 2020.

Bauman, Zygmunt, Globalização: as consequências humanas, Rio de Janeiro: Zahar, 1999.

Brasil, Presidência da República, [Estatuto do Estrangeiro], Lei nº 6815, de 19 de agosto de 1980, Define a situação jurídica do estrangeiro no Brasil, cria o Conselho Nacional de Imigração, Brasília, DF: Presidência da República, 1980, Disponível em: http://www.planalto.gov.br/ ccivil_03/leis/16815.htm, Acesso em 14 de ago. de 2020.

Brasil, Presidência da República, Constituição da República Federativa do Brasil, de 05 de outubro de 1988, Brasília, DF: Presidência da República, 1988, Disponível em: http://www.planalto.gov.br/ ccivil_03/constituicao/constituicao.htm, Acesso em 14 de ago. de 2020.

Brasil, Senado Federal, Projeto de Lei do Senado 288/2013, Brasília, DF: Senado Federal, 2013, Disponível em: https://www25.senado.leg.br/web/atividade/materias/-/materia/113700, Acesso em 14 de ago. de 2020.

Brasil, Presidência da República, Mensagem de Veto à Lei 13.445, 24 de maio de 2017, Brasília, DF: Presidência da República, 2017a, Disponível em: http://www.planalto.gov.br/ccivil_03/ _ato2015-2018/2017/msg/vep-163.htm, Acesso em 14 de ago de 2020.

Brasil, Presidência da República, [Nova Lei de Migração Brasileira (NLM)], Lei 13.445, 24 de maio de 2017, Institui a Lei de Migração, Brasília, DF: Presidência da República, 2017b, Disponível em: http://www.planalto.gov.br/ccivil_03/_ato2015-2018/2017/lei/l13445.htm, Acesso em 14 de ago. de 2020 . 
Brasil, Presidência da República, Decreto nº 9.285, de 15 de fevereiro de 2018, Brasília, DF: Presidência da República, 2018a, Disponível em: http://www.planalto.gov.br/ccivil_03/_ato2015-2018/2018/ decreto/D9285.htm, Acesso em 05 de ago. de 2020.

Brasil, Presidência da República, Portaria Interministerial nº 9, de 14 de março de 2018, Brasília, DF: Presidência da República, 2018b, Disponível em: https://www.in.gov.br/materia/-/ asset_publisher/Kujrw0TZC2Mb/content/id/6653698/do1-2018-03-15-portaria-interministerialn-9-de-14-de-marco-de-2018-6653694, Acesso em 05 de ago. de 2020.

Brasil, Presidência da República, Lei nº 13.979, de 6 de fevereiro de 2020, Brasília, DF: Presidência da República, 2020a, Disponível em: http://www.planalto.gov.br/ccivil_03/_ato2019-2022/2020/lei/ 113979.htm, Acesso em 10 de ago. de 2020.

Brasil, Presidência da República, Portaria nº 132, de 22 de março de 2020, Brasília, DF: Presidência da República, 2020d, Disponível em: http://www.planalto.gov.br/ccivil_03/portaria/prt132-20ccv.htm, Acesso em 10 de ago. de 2020.

Brasil, Presidência da República, Portaria nº 133, de 23 de março de 2020, Brasília, DF: Presidência da República, 2020e, Disponível em: http://www.planalto.gov.br/ccivil_03/Portaria/PRT/ Portaria\%20n\%C2\%BA\%20133-20-CCV.htm, Acesso em 10 de ago. de 2020.

Brasil, Presidência da República, Lei nº 14.035, de 11 de agosto de 2020, Brasília, DF: Presidência da República, 2020h, Disponível em: https://www.in.gov.br/en/web/dou/-/lei-n-14.035-de-11-deagosto-de-2020-271717691, Acesso em 14 de ago. de 2020.

Brasil, Ministério da Justiça e Segurança Pública, Portaria Interministerial nº 120, de 17 de março de 2020, Brasília, DF: Ministério da Justiça e Segurança Pública, 2020b, Disponível em: http:// www.planalto.gov.br/CCIVIL_03/Portaria/prt120-20-ccv.htm, Acesso em 10 de ago. de 2020.

Brasil, Ministério da Justiça e Segurança Pública, Portaria nº 125, de 19 de março de 2020, Brasília, DF: Ministério da Justiça e Segurança Pública, 2020c, Disponível em: http://www.planalto.gov.br/ CCIVIL_03/Portaria/prt125-20-ccv.htm, Acesso em 10 de ago. 2020.

Brasil, Ministério da Justiça e Segurança Pública, Portaria nº 152, de 27 de março de 2020, Brasília, DF: Ministério da Justiça e Segurança Pública, 2020f, Disponível em: http://www.planalto.gov.br/ ccivil_03/Portaria/PRT/Portaria\%20n\%C2\%BA\%20152-20-ccv.htm, Acesso em 10 ago, 2020.

Brasil, Ministério da Justiça e Segurança Pública, Portaria nº 255, de 22 de maio de 2020, Brasília, DF: Ministério da Justiça e Segurança Pública, 2020g, Disponível em: https://www.in.gov.br/en/web/ dou/-/portaria-n-255-de-22-de-maio-de-2020-258114133, Acesso em 10 ago. 2020.

CONARE (Comitê Nacional para os Refugiados), Projeto de Cooperação para Análise das decisões de Refúgio no Brasil, Disponível em: https://www.gov.br/mj/pt-br/assuntos/seus-direitos/refugio/, Acesso em 01 de ago. de 2020.

Fernandes, Duval; Leão, Augusto Veloso, "Políticas de imigração no contexto da pandemia de COVID-19”, In: Baeninger, Rosana; Fernandes, Duval, Impactos da Pandemia de COVID-19 nas Migrações Internacionais no Brasil: resultados de pesquisa, Campinas: NEPO/UNICAMP, 2020.

Kenicke, Pedro Henrique Gallotti, O Estatuto do Estrangeiro e a Lei de Migrações: entre a doutrina da segurança nacional e o desenvolvimento humano, Dissertação de mestrado em Direito do Estado, Curitiba: Universidade Federal do Paraná, 2016.

Koifman, Fábio, Imigrante Ideal: o Ministério da Justiça e a entrada de estrangeiros no Brasil (1941-1945), Rio de Janeiro: Civilização Brasileira, 2012.

Kowarick, Lúcio, Trabalho e Vadiagem: a origem do trabalho livre no Brasil, São Paulo: Editora Paz e Terra, 1994. 
Lassale, Ferdinand, A Essência da Constituição, Rio de Janeiro: Liber Juris, 1988.

Lesser, Jeffrey, A Invenção da Brasilidade: identidade nacional, etnicidade e políticas de imigração, São Paulo: editora UNESP, 2015.

Martínez, Jorge; ORREGO, Cristián, “Nuevas tendencias y dinámicas migratorias en América Latina y el Caribe", Serie Población y Desarrollo, n. 114. Santiago: CEPAL, OIM, 2016.

Moreira, Julia Bertino, "Migrações internacionais à luz da pandemia do novo coronavírus", Revista Com Ciência, Disponível em: https://www.comciencia.br/migracoes-internacionais-a-luzda-pandemia-do-novo-coronavirus-covid-19/, Acesso em 30 de jul. 2020.

OIM (Organização Internacional para as Migrações), Migration Data Portal, Disponível em: https:// www.migrationdataportal.org/international-data?i=stock_abs_\&t=2020, Acesso em

Oliveira, Antônio Tadeu Ribeiro de, "Nova lei brasileira de migração: avanços, desafios e ameaças", Revista Brasileira de Estudos de População, v.34, n.1, 2017, pp. 171-179.

ONU (Organização das Nações Unidas), Declaração Universal dos Direitos Humanos, Nova York, Estados Unidos, 1948, Disponível em: https://www.ohchr.org/EN/UDHR/Pages/Language.aspx? LangID=por.

Patarra, Neide Lopes, “O Brasil: país de imigração?” Revista e-Metropolis: Revista Eletrônica de Estudos Urbanos e Regionais, n. 9, ano 3, 2012.

Pelligrino, Adela, "La migración internacional en América Latina y el Caribe: tendencias y perfiles de los migrantes", Serie Población y Desarrollo, n. 35, Santiago: CEPAL, 2003.

R4V (Plataforma Regional de Coordinación Interagencial para Refugiados y Migrantes de Venezuela), América Latina y el Caribe, Refugiados y Migrantes Venezolanos en la Región - Agosto 2021, Disponível em: https://www.r4v.info/es/document/r4v-america-latina-y-el-caribe-refugiados-ymigrantes-venezolanos-en-la-region-agosto-2021, Acesso em 03 de set. de 2021.

Santos, Aline Lima; Rossino, Rosa Ester, Reflexões geográficas sobre migrações, desenvolvimento e gênero no Brasil, In: Baeninger, Rosana; Bógus, Lucia; Vedovato, Luís Renato; Fernandes, Duval; et al (org), Migrações Sul-Sul, Campinas: Núcleo de Estudos de Populações (NEPO/Unicamp), 2018.

Seyferth, Giralda, "Imigração, colonização e identidade étnica: notas sobre a emergência da etnicidade em grupos de origem europeia no sul do Brasil”, Revista de Antropologia, n. 29, 1986.

Seyferth, Giralda, “A assimilação do imigrante como questão nacional”, Revista MANA, v. 3, 1997.

Seyferth, Giralda, “A dimensão cultural da imigração”, Revista Brasileira de Ciências Sociais, v. 23, n. 77, 2011.

Simi, Gianlluca, “A metafísica do estrangeiro: um ensaio sobre o conceito de", In: Redin, Giuliana, Migrações Internacionais: experiências e desafios para a proteção e promoção de direitos humanos no Brasil, Santa Maria: Editora UFSM, 2020.

Sprandel, Marcia Anita, “Migração e crime: a Lei 6.815, de 1980", REMHU: Revista Interdisciplinar da Mobilidade Humana, n. 45, ano 23, 2015, p. 145-168.

Sprandel, Marcia Anita, "Leis migratórias e conservadorismo parlamentar no Brasil: o caso da Lei 13.445, de 2017”, Cadernos de Debates: Refúgio, Migrações e Cidadania, v. 13, n. 13, 2018.

Vedovato, Luis Renato; Assis, Ana Elisa Spaolonzi Queiroz, “Os vetos à nova Lei de Migração brasileira: a interpretação como um passo necessário”, In. Baeninger, Rosana; Bógus, Lúcia Machado; Vedovato, Luís Renato; Fernandes, Duval (org.), Migrações Sul-Sul, Campinas: Núcleo de Estudos de População - Nepo/Unicamp, 2018. 
Ventura, Deisy, “Mobilidade humana e saúde global”, Revista USP, n. 107, p. 55-64, 2015.

Ventura, Deisy, "The impact of international health crises on the rights of migrants", Revista SUR, v. 13, n. 23 , p. $61-75,2016 a$.

Ventura, Deisy; Holzhacker, Vera, Saúde Global e Direitos Humanos: o primeiro caso suspeito de Ebola no Brasil, Revista Lua Nova, n. 98, 2016b.

Villarreal, María; Granja, Lorena, “Mercosur migrante: enfoques y evolución del tratamiento de la movilidad humana en el MERCOSUR”, Revista Terceiro Milênio: Revista Crítica de Sociologia e Política, v. 8, n. 1, 2017, pp. 49-78.

Villarreal, María, "Regionalismos e Migrações internacionais na América do Sul: contexto e perspectivas futuras sobre as experiências na comunidade andina, no Mercosul e na Unasul", Revista Espaço Aberto, v. 8, n. 2, 2018, pp. 131-148.

Villarreal, Maria, “Portas não tão abertas”, Revista de Divulgação Científica - Coletiva, 2019, pp. 1-13.

Villarreal, María; Echart, Enara; Carballo, Marta, "El enfoque de sistemas migratórios revisitado: una propuesta teórica para el estudio del sistema migratorio de América Latina y el Caribe", REMHU: Revista Intersisciplinar da Mobilidade Humana, v. 27, n. 57, 2019, pp. 79-100.

Villarreal, María, "Migrações na América Latina em tempos de coronavírus”, Jornal Folha de São Paulo, Disponível em: https://www1.folha.uol.com.br/mundo/2020/04/migracoes-na-americalatina-em-tempo-de-coronavirus.shtml, Acesso em 30 de jul. 2020.

WHO (World Health Organization), Coronavirus disease (COVID-19), Disponível em: https:// www.who.int/health-topics/coronavirus\#tab=tab_1, Acesso em 30 de jul. 2020.

\section{NOTAS}

1. “A divisão Sul/Norte Global é um tanto arbitrária não coincidindo com os hemisférios separados pela linha do Equador. Trata-se sobretudo de uma tipologia calcada em considerações sobre o desenvolvimento em escala planetária. Tais discussões foram historicamente marcadas pela dimensão econômica, predominando critérios como o PIB ou a renda per capita para definir e categorizar os países do Sul e do Norte." SANTOS, Aline Lima; ROSSINI, Rosa Ester. Reflexões geográficas sobre migrações, desenvolvimento e gênero no Brasil. In: BAENINGER, Rosana; BÓGUS, Lucia; VEDOVATO, Luís Renato; FERNANDES, Duval; et al (org). Migrações Sul-Sul. Campinas: Núcleo de Estudos de Populações (NEPO/Unicamp), 2018, pp. 279.

2. ACNUR (Agência da ONU para Refugiados). Venezuela. Disponível em: https://www.acnur.org/ portugues/venezuela/. Acesso em 04 de jul. de 2020.

3. R4V (Plataforma Regional de Coordinación Interagencial para Refugiados y Migrantes de Venezuela). América Latina y el Caribe, Refugiados y Migrantes Venezolanos en la Región Agosto 2021. Disponível em: https://www.r4v.info/es/document/r4v-america-latina-y-el-cariberefugiados-y-migrantes-venezolanos-en-la-region-agosto-2021. Acesso em 03 de set. de 2021.

4. ACNUR (Agência da ONU para Refugiados). Dados sobre Refúgio. Disponível em: https:// www.acnur.org/portugues/dados-sobre-refugio/. Acesso em 04 de jul. de 2020.

5. O CONARE um órgão colegiado, vinculado ao Ministério da Justiça e Segurança Pública, que delibera sobre as solicitações de reconhecimento da condição de refugiado no Brasil. Disponível em: https://legado.justica.gov.br/seus-direitos/refugio/conare. Acesso em 05 de set. 2021. 
6. CONARE (Comitê Nacional para os Refugiados). Projeto de Cooperação para Análise das decisões de Refúgio no Brasil. Disponível em: https://www.gov.br/mj/pt-br/assuntos/seusdireitos/refugio/. Acesso em 10 de jul. de 2020.

7. R4V (Plataforma Regional de Coordinación Interagencial para Refugiados y Migrantes de Venezuela). América Latina y el Caribe, Refugiados y Migrantes Venezolanos en la Región Agosto 2021. Disponível em: https://www.r4v.info/es/document/r4v-america-latina-y-el-cariberefugiados-y-migrantes-venezolanos-en-la-region-agosto-2021. Acesso em 03 de set. de 2021.

8. OIM (Organização Internacional para as Migrações). Migration Data Portal. Disponível em: https://www.migrationdataportal.org/international-data?i=stock_abs_\&t=2020. Acesso em $01 \mathrm{de}$ jul. de 2020.

9. Para maiores esclarecimentos sobre a relação abstrata entre Direito e respostas sanitárias ver: MAGNUSSON, Roger. Advancing the right to health: the vital role of law. Advancing the Right to Health: The Vital Role of Law, World Health Organization, Switzerland, 2017.

10. "Os fatores reais de poder que atuam no seio de cada sociedade são essa força ativa e eficaz que informa todas as leis e instituições jurídicas vigentes, determinando que não possam ser, em substância, a não ser tal como elas são". LASSALE, Ferdinand. A Essência da Constituição. Rio de Janeiro: Liber Juris, 1988, p.11.

11. Em 11 de agosto de 2020 o Brasil sancionou a Lei $n^{\circ} 14.035 / 2020$ reeditando a Lei $n^{\circ}$ 13.979/2020, de 6 de fevereiro de 2020.

12. No momento em que o artigo foi produzido, a Portaria $n^{\circ} 255 / 2020$ era o último ato normativo sobre o tema a ser publicado pelo governo brasileiro.

\section{RESUMOS}

O ano de 2020 inicia com a pandemia provocada pelo novo coronavírus, trazendo novas dinâmicas que se tornaram imperativas entre os países: o fechamento de fronteiras e a restrição da circulação de pessoas. Tais medidas puderam ser observadas em diferentes países como principais alternativas de controle da disseminação do vírus da COVID-19. Os efeitos da pandemia e do fechamento de fronteiras, no caso brasileiro, demonstraram um aspecto já conhecido nos contextos de migração histórica e contemporânea no Brasil: a seletividade migratória e a adoção de medidas restritivas mediadas e catalisadas por categorias jurídicas. Sendo assim, apresenta-seá uma análise conjectural dos primeiros atos normativos, no âmbito do Brasil, em diálogo com seu tratamento específico aos venezuelanos, comparando-os entre si, para assim observar as questões subjacentes à produção normativa do caso relacionado.

The year 2020 begins with the pandemic caused by the new coronavirus, bringing new dynamics that have become rules between countries: the closing of borders and the restriction of people's circulation. Such measures could be observed in different countries as the main alternatives for controlling the dissemination of the COVID-19 virus. The effects of the pandemic and the closing of borders, in the Brazilian case, demonstrated an aspect already known in the contexts of historical and contemporary migration in Brazil: migratory selectivity and the adoption of restrictive measures mediated by legal categories. Thus, a conjectural analysis of the first normative acts in Brazil will be presented, in dialogue with their specific treatment of Venezuelans, comparing them to each other, in order to observe the issues underlying the normative production of the related case. 
L'année 2020 commence avec la pandémie causée par le nouveau coronavirus, apportant de nouvelles dynamiques devenues impératives entre les pays : la fermeture des frontières et la restriction de la circulation des personnes. De telles mesures pourraient être observées dans différents pays comme les principales alternatives pour contrôler la dissémination du virus COVID-19. Les effets de la pandémie et de la fermeture des frontières, dans le cas brésilien, ont démontré un aspect déjà connu dans les contextes migratoires historiques et contemporains au Brésil: la sélectivité migratoire et l'adoption de mesures restrictives médiatisées par des catégories juridiques. Ainsi, une analyse conjecturale des premiers actes normatifs au Brésil sera présentée, en dialogue avec leur traitement spécifique des Vénézuéliens, en les comparant les uns aux autres, afin d'observer les enjeux sous-jacents à la production normative du cas concerné.

\section{ÍNDICE}

Keywords: Migration, Covid-19, Borders, Brazil, Venezuela.

Mots-clés: Migration, Covid-19, Limites, Brésil, Venezuela.

Palavras-chave: Migração, Covid-19, Fronteiras, Brasil, Venezuela.

\section{AUTORES}

\section{NICOLLI BERNARDES RIBEIRO}

Mestranda no Programa de Pós-Graduação em Sociologia e Direito da Universidade Federal Fluminense. Graduada em Sociologia pela Universidade Federal Fluminense. Pesquisadora no Grupo de Pesquisa em Relações Internacionais e Sul Global (GRISUL/UNIRIO), no Núcleo de Pesquisas sobre Imigração do Grupo Sociologia, Direito e Justiça (PPGSD/UFF). E-mail: nicollibernardes@gmail.com

\section{LUCAS SENA}

Mestre em Ciências Sociais e Direito pela Universidade Federal Fluminense. Graduado em Direito pela Universidade Cândido Mendes. Autor do livro "Canetadas, Chefia e Anestesia Jurídica: 0 direito sendo utilizado para encobrir conflitos sociais", publicado pela Editora Dialética em 2021. E-mail. lkssena@gmail.com 